AL-MARSHAD: JURNAL ASTRONOMI ISLAM DAN ILMU-ILMU BERKAITAN

ISSN 2442-5729 (print) || ISSN 2598-2559 (online), http://jurnal.umsu.ac.id/index.php/almarshad

DOI: $\underline{\text { https://doi.org/10.30596/jam.v4i2.2441 }}$

Published December 2018

\title{
Penetapan Awal Bulan Kamariah \\ dan Permasalahannya di Indonesia
}

\author{
Dedi Jamaludin \\ Pengadilan Agama Tasikmalaya \\ Email: jamalaristo@gmail.com
}

\begin{abstract}
Determination of the beginning of the lunar month in Islam begins with the appearance of the new moon, which is an issue of ijtihad. Based on research shows that in rukyat there are many weaknesses so that this method needs to be elaborated with modern technology (in this case reckoning). Research and calculations carried out by experts on reckoning show that the data generated has always provided very accurate results without leaving significant differences. Basically, Reckoning is a scientific building, so it is strongly influenced by each epistemic discourse. Wujudul hilal carried by Muhammadiyah and imkanur rukyat by the Government has its own characteristics. So, the limit of equilibrium (read: balance) reckoning and imkanur rukyat lies in the extent to which the two communicate with each other, rather than taking distance.
\end{abstract}

Keywords: Early Month, Reckoning, Rukyat, Matlak

Artikel Info

Received:

10 September 2018

Revised:

04 Oktober 2018

Accepted:

10 November 2018

\begin{abstract}
Abstrak
Penetapan awal bulan kamariah dalam Islam diawali dengan munculnya hilal, yang merupakan persoalan ijtihad. Berdasarkan penelitian menunjukkan bahwa dalam rukyat terdapat banyak kelemahan sehingga metode ini perlu dielaborasi dengan teknologi modern (dalam hal ini hisabfalak). Penelitian dan perhitungan yang dilakukan para pakar hisab-falak menunjukkan bahwa data yang dihasilkan sudah selalu memberikan hasil yang sangat akurat tanpa menyisakan perbedaan yang berarti. Hisab pada dasarnya adalah bangunan keilmuan, maka sangat dipengaruhi oleh wacana epistema masing-masing. Wujudul hilal yang diusung Muhammadiyah dan imkanur rukyat oleh Pemerintah memiliki ciri sendiri-sendiri. Maka, batas equilibrium (baca: keseimbangan) hisab dan imkanur rukyat terletak pada sampai mana keduanya saling berkomunikasi, bukan malah mengambil jarak.
\end{abstract}

Kata Kunci: Awal Bulan, Hisab, Rukyat, Matlak 


\section{A. Pendahuluan}

Sebagaimana

diketahui, penetapan awal bulan kamariah dalam Islam diawali dengan munculnya hilal, yaitu bulan sabit yang pertama kali terlihat, yang selanjutnya membesar menjadi bulan purnama, menipis kembali, dan akhirnya menghilang dari langit sebagaimana diisyaratkan dalam QS. Al-Baqarah [02] ayat 189. Di dalam al-Qur'an banyak ayat-ayat yang membicarakan peredaran benda-benda angkasa atau setidak-tidaknya bernuansa astronomis, antara lain:

- Surat Al-An'am [06] ayat 96:

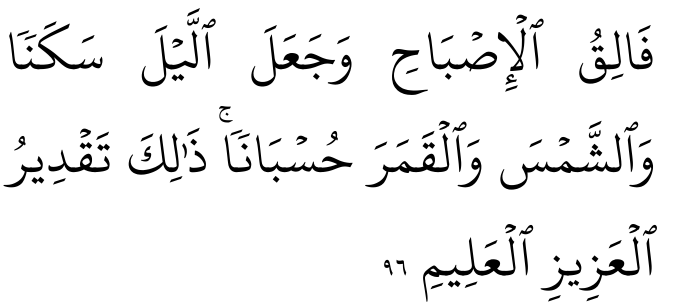

Artinya: "Dia menyingsingkan pagi dan menjadikan malam untuk beristirahat, dan (menjadikan) matahari dan bulan untuk perhitungan. Itulah ketentuan Allah Yang Maha Perkasa lagi Maha Mengetahui." (QS. Al An'am [06]: 96)

- Surat Yunus [10] ayat 5:

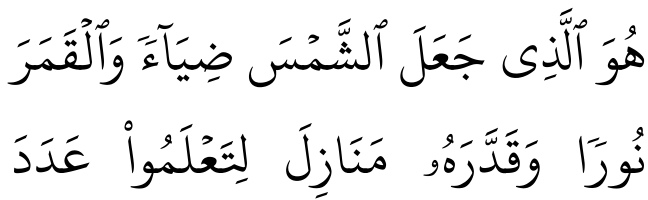

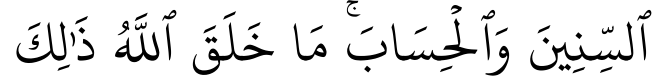
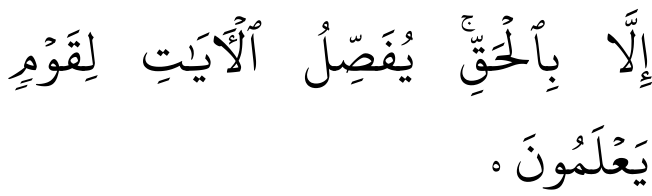

Artinya: "Dia-lah yang menjadikan matahari bersinar dan bulan bercahaya dan ditetapkan-Nya manzilah-manzilah (tempat-tempat) bagi perjalanan bulan itu, supaya kamu mengetahui bilangan tahun dan perhitungan (waktu). Allah tidak menciptakan yang demikian itu melainkan dengan hak. Dia menjelaskan tanda-tanda (kebesaranNya) kepada orang-orang yang mengetahui". (QS. Yunus [10]: 5)

- Surat Al-Baqarah [20] ayat 189:

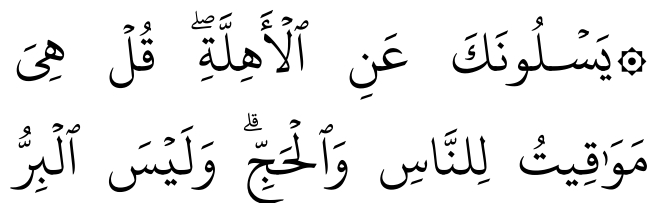

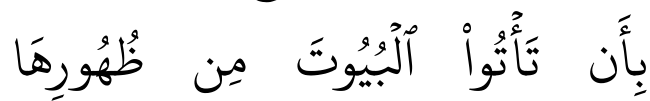

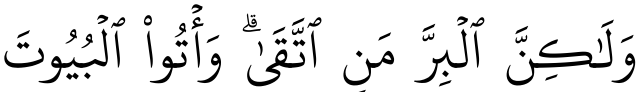

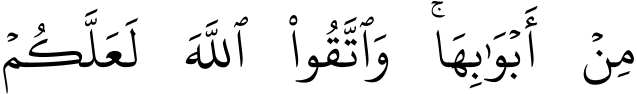
نُفْلِحُحونَ

Artinya: "Mereka bertanya kepadamu tentang bulan sabit. Katakanlah: "Bulan sabit itu adalah tanda-tanda waktu bagi manusia dan 
AL-MARSHAD: JURNAL ASTRONOMI ISLAM DAN ILMU-ILMU BERKAITAN

ISSN 2442-5729 (print) || ISSN 2598-2559 (online), http://jurnal.umsu.ac.id/index.php/almarshad

DOI: $\underline{\text { https://doi.org/10.30596/jam.v4i2.2441 }}$

Published December 2018

(bagi ibadah) haji ...". (QS. AlBaqarah [02]: 189)

Ketiga ayat diatas secara zahir menyatakan bahwa perhitungan bilangan tahun dan perhitungan waktuwaktu lainnya adalah melalui pergerakan matahari dan bulan. Islam mengajarkan pembagian bulan dengan tanda keluarnya bulan sabit. Ayat ketiga (QS. Al-Baqarah [02] ayat189) menyatakan perbedaan kalender Islam dengan yang lainnya. Selain tiga ayat diatas, masih terdapat ayat-ayat lain yang berbicara tentang fenomena astronomi.

Satu tahun kamariah (lunar year) adalah jangka waktu yang dibutuhkan bulan mengelilingi bumi selama 12 kali putaran dengan rata-rata satu tahun lamanya 354 11/30 hari. Berbeda dengan tahun matahari (solar year) yaitu jangka waktu yang dibutuhkan oleh bumi untuk mengelilingi matahari (berevolusi) dengan rata-rata satu tahun lamanya 365 1/4 hari. ${ }^{1}$ Imu astronomi mutakhir sudah sangat akurat memperhitungkan dan memperkirakan terlihatnya hilal

1 Farid Ruskanda, 100 Masalah Hisab \& Rukyat, Telaah Syari'ah, Sains dan Teknologi, (Gema Insani Press, 1996), h.14. dengan sangat teliti, tingkat ketelitian ini sudah lebih dari cukup untuk keperluan teknis penentuan awal-awal bulan kamariah, namun dalam penentuan awal Ramadhan-Syawal dan Dzulhijah persoalan tidak sederhana, hadis Nabi Saw menyatakan awal dan akhir Ramadhan ditetapkan lewat pengamatan hilal.

\section{B. Karakteristik Hilal dan Fase-Fase \\ Bulan}

Salah satu hal yang sangat penting untuk diketahui dalam permasalahan penetapan awal bulan kamariah adalah karakteristik hilal dan fase-fase bulan. Hilal sebagai obyek utama dalam menentukan awal bulan merupakan benda (fenomena) angkasa langka yang tak semua orang dapat dan mampu melihatnya. Perubahan penampakan wajah bulan setiap harinya, seperti yang terlihat dari bumi, adalah sebagai akibat posisi relatif bulan terhadap bumi dan matahari. Wajah bulan nampak berbeda dari waktu ke waktu yang disebut fase-fase bulan. Fase-fase tersebut adalah:

1. Crescent (al-hilâl), yaitu posisi (manzilah) pertama bulan ketika menuju langit utara, yang jika 
memungkinkan akan terlihat di ufuk barat setelah matahari terbenam. Kejelasan bentuk hilal dari satu bulan dengan bulan lain berbeda-beda, masa muncul dan terlihatnyapun berbeda-beda, yaitu antara 10 s.d. 40 menit. Bentuk hilal hari-hari berikutnya akan semakin jelas dan membesar, hingga mencapai 6 hari 16 jam 11 menit hilal akan beralih pada posisi dan bentuk lain yaitu first quarter (at-tarb $\hat{\imath}^{\prime}$ al-awwal).

2. First Quarter (at-tarbî' al-awwal), adalah bulan yang telah memasuki $1 / 4$ peredarannya pada bumi, yaitu mulai dari hari ke-7.

3. First Gibbous (al-ahdab al$a w w a l)$, yaitu bulan yang sudah mulai mendekati ufuk timur, dengan bentuknya yang sudah semakin membesar, yaitu telah sampai heri ke-11, dengan lengkung sabit menghadap ke timur.

4. Full Moon (al-badr), yaitu bulan yang telah mencapai usia pertengahan dimana posisinya tepat berhadapan dengan matahari, dan bentuknya telah bulat sempurna.

5. Second Gibbous (al-ahdab atstsânî), yaitu masa setelah berlalunya full moon (al-badr) yang hampir seukuran dengan alhadab al-awwal namun dengan arah lengkung sabit yang berlawanan (menghadap ke barat).

6. Second Quarter (at-tarbî' atstsânî), yaitu masa bulan yang telah berlalu sekitar 22 1/8 hari yang mirip at-tarbi' al-awwal, namun dengan arah lengkung sabit yang berkebalikan, yang terus bergerak sedikit demi sedikit menuju arah ufuk barat.

7. Second Crescent (al-hilâl a-tsânî), yaitu masa setelah berlalunya attarbî̀ ats-tsânî, dimana cahayanya menutupi sebagian kecil bagian kanan yang berbentuk seperti hilal.

8. Wane (al-mahâq), yaitu masa sampainya bulan pada peredaran sempurna, dimana bumi, bulan, dan matahari dalam posisi sejajar (pada garis bujur), yang disebut dengan konjungsi/ijtimak (hâlah al-iqtirân), dan nyaris tidak terlihat dari bumi dikarenakan 
AL-MARSHAD: JURNAL ASTRONOMI ISLAM DAN ILMU-ILMU BERKAITAN

ISSN 2442-5729 (print) || ISSN 2598-2559 (online), http://jurnal.umsu.ac.id/index.php/almarshad

DOI: https://doi.org/10.30596/jam.v4i2.2441

Published December 2018

gelap (bagian bulan yang menghadap ke bumi adalah bagian yang gelap/tidak disinari matahari). ${ }^{2}$

Konjungsi (ijtimâ', iqtirân) sebagai syarat awal masuknya bulan baru adalah saat bulan berada di antara matahari dan bumi (fase wane, almahâq), dimana wajah bulan menjadi tidak tampak dari bumi. Secara detail, ijtimak merupakan pertemuan atau berimpitnya dua benda yang berjalan secara aktif. Pengertian ijtimak bila dikaitkan dengan bulan baru kamariah adalah suatu peristiwa saat bulan dan matahari terletak pada posisi garis bujur yang sama, bila dilihat dari arah timur ataupun arah barat. Pada saat itu bulan sangat sulit terlihat dari bumi dikarenakan bagian bulan yang menghadap ke bumi adalah bagian yang gelap/tidak disinari matahari. Sekalipun ada, hilal sangat tipis sekali dan nyaris tak dapat dilihat karena bulan yang sedang berijtimak, berdekatan letaknya dengan matahari. Mengetahui saat terjadinya ijtimak sangat penting dalam

2 Arwin Juli Rakhmadi Butar-Butar, Aspek Astronomis Penentuan Awal Bulan Qamariyah; Karakteristik Hilal dan Plus-Minus Hisab Astronomis, (Kairo: ICMI ORSAT, 2007), h. 1-2. penentuan awal bulan kamariah. Semua astronom (ahli hisab) sepakat bahwa peristiwa ijtimak merupakan batas penentuan secara astronomis antara bulan kamariah yang sedang berlangsung dan bulan kamariah berikutnya. Oleh karena itu, para ahli astronomi umumnya menyebut ijtimak atau konjungsi sebagai awal perhitungan bulan baru, yang dalam ilmu falak dikemukakan bahwa ijtimak antara bulan dan matahari merupakan batas dua bulan kamariah. ${ }^{3}$

\section{Rukyat}

Di Indonesia yang memakai metode rukyat (rukyat bil fi'li) adalah Nahdlatul Ulama (NU). ${ }^{4}$ Pada dasarnya, antara rukyat dan hisab tidaklah bertentangan selama keduanya dilakukan berdasarkan data dan fakta yang benar. Rukyat, sebagai sarana sederhana yang telah teruji, pula terbukti dipraktekkan baginda Nabi Saw dan sahabat selama bertahun-tahun

\footnotetext{
${ }^{3}$ Ibid.

${ }^{4}$ Ghazalie Masroerie, Penentuan Awal Bulan Qamariyah perspektif Nahdlatul 'Ulama, dalam Kumpulan Makalah Workshop Nasional Metodologi Penetapan Awal Bulan Qamariyah Model Muhammadiyah di Kampus Terpadu Universitas Muhammadiyah Yogyakarta tahun 2002, [Majelis Tarjih Dan Pengembangan Pemikiran Islam Pimpinan Pusat Muhammadiyah], h. 1.
} 
AL-MARSHAD: JURNAL ASTRONOMI ISLAM DAN ILMU-ILMU BERKAITAN

ISSN 2442-5729 (print) || ISSN 2598-2559 (online), http://jurnal.umsu.ac.id/index.php/almarshad

DOI: $\underline{\text { https://doi.org/10.30596/jam.v4i2.2441 }}$

Published December 2018

merupakan tata cara yang terus dipertahankan dan dapat digunakan sampai kapanpun. Namun demikian, maju dan meluasnya peradaban Islam membawa konsekuensi kepada semakin sulit dan serampangannya praktek rukyat dalam menentukan awal bulan. Klaim-klaim melihat hilal sering kali muncul, meski realitas menyatakan yang terlihat bukan hilal, maka di sini diperlukan catatan-catatan rinci tentang hilal dan rukyat yang dimaksud.

Hisab astronomis, yang merupakan akses majunya peradaban, merupakan fakta yang tidak terbantah telah banyak bahkan sangat banyak membantu dan memudahkan ibadah umat Islam. Keteraturan alam raya nan luas ini dapat dideteksi secara cermat oleh ilmu ini.

Terdapat beberapa aspek ilmiah hilal yang sangat perlu dipahami, yaitu:

1. Bulan terbenam lebih dulu dari matahari (hilal masih berada di bawah ufuk, alias hilal negatif). Dalam keadaan ini hilal mustahil terlihat, dan setiap kesaksian ditolak.

2. Bulan terbenam setelah terbenamnya matahari. Dalam keadaan ini, ada kemungkinan hilal terlihat, namun bergantung pada ketinggiannya di atas ufuk untuk dapat teramati.

3. Hilal terlihat setelah terbenamnya matahari sebelum terjadinya ijtimak/konjungsi. Hal ini belum terhitung awal bulan, namun masih terhitung sebagai hilal akhir bulan yang sedang berjalan. (fenomena ini terhitung sebagai kejadian yang ganjil dan jarang terjadi).

4. Terjadinya konjungsi ketika terbenamnya matahari dalam keadaan tertutup, yaitu terjadinya gerhana matahari, maka dipastikan hilal tidak akan terlihat.

5. Bulan terbenam setelah terbenamnya matahari di sebagian wilayah, sementara itu wilayah lain sebaliknya. Maka dalam hal ini, setiap wilayah berlaku matlak masing-masing berlandaskan hadis Kuraib, sementara jika hal itu terjadi dalam satu wilayah negara kesatuan dapat diputuskan melalui prinsip wilayatul hukmi.

6. Bulan terbenam sebelum terbenamnya matahari di sebagian wilayah, sementara di wilayah lain sebaliknya. Maka, rukyah berlaku pada mabda' (matlak') masing- 
masing, dan terkadang point $4,5,6$ dikembalikan kepada penguasa sebagai ulil amri. Enam keadaan di atas merupakan fakta ilmiah hilal yang perlu dipahami secara baik.

Dalam aktifitas rukyat, sebagaimana tertera dalam fikih maupun hadis, diperlukan adanya saksi adil. Kriteria ulama dalam hal ini adalah; (1). Sehat badan dan fikiran. (2). Jelas penglihatan. (3). Jujur dan terpercaya. (4). Memahami teks dan konteks rukyat, yang keempat syarat ini dikemas dengan sumpah. Berikutnya hal-hal yang harus sangat diperhatikan dalam pelaksanaan rukyat, berhubungan dengan poin 4 adalah:

1. Pemahaman lapangan rukyat; area rukyat terideal adalah pinggir laut lepas dan bebas tanpa penghalang berupa gunung, pohon, bangunan, dan lain-lain (atau tempat yang tinggi), ditambah kondisi ufuk barat dalam keadaan cerah.

2. Waktu pelaksanaan rukyat; yaitu semenjak terbenam matahari setelah terjadi konjungsi hingga berlalunya masa munculnya hilal, dimana berdasar penelitian hilal hanya hadir sekitar 10 menit s.d. 1 jam saja.
3. Keadaan hilal; hilal tanggal satu adalah hilal yang tanduknya sedikit mengarah ke timur, jika sedikit mengarah ke bawah (barat) maka itu bukan hilal bulan baru, dan masih terhitung hilal akhir bulan, dan bentuk hilal sangat tipis dan redup.

4. Posisi hilal; kemunculan hilal akan berada di arah mana, apakah di sebelah utara matahari, selatan, atau di atas tempat terbenamnya matahari.

5. Umur hilal; minimal 8 jam semenjak terjadinya konjungsi (dalam kesepakatan MABIMS), karena umur hilal akan berpengaruh terhadap kejelasan bentuk dan sinar yang akan muncul.

Persoalam lain yang tak kalah pentingnya terkait hal ini adalah persoalan teknis dari hilal dan rukyat itu sendiri, seperti; 'hilal' apa yang dilihat? Benarkah benda yang dilihat memang hilal? kapan (jam) berapa hilal itu muncul dan bisa terlihat? Berikutnya bagaimana bentuk hilal itu? Diposisi mana dari perukyat hilal itu muncul?. Ringkasnya, apa, bagaimana, berapa, berapa lama, kapan dan di mana hilal itu? Ini merupakan deretan pertanyaan 
AL-MARSHAD: JURNAL ASTRONOMI ISLAM DAN ILMU-ILMU BERKAITAN

ISSN 2442-5729 (print) || ISSN 2598-2559 (online), http://jurnal.umsu.ac.id/index.php/almarshad

DOI: https://doi.org/10.30596/jam.v4i2.2441

Published December 2018 teknis yang harus terlebih dahulu dipahami secara baik oleh para perukyat atau penganut rukyat, sebab kenyataan di lapangan, banyak perukyat yang tidak memahami hal-hal di atas. Meski telah dilegalisir dengan sumpah, persoalan-persoalan teknis di atas seharusnya dipahami terlebih dahulu, namun sayang, banyak bahkan kebanyakan pendukung rukyat tidak memahami persoalan teknis hilal dan rukyat tersebut, yang terjadi hanyalah tunduk patuh terhadap literalis hadis dan laporan rukyat tanpa riset dan reserve ilmiah. Rukyat sahih menuntut praktek tepat yang terkait dengan tiga fenomena alami benda angkasa ciptaan Allah Swt (bumi, bulan, dan matahari).

Dari keterangan di atas dapat disimpulkan bahwa kesaksian rukyat dapat diterima jika memenuhi kriteria di atas. Jika satu saja dari kriteria-kriteria itu tidak terpenuhi, kesaksian tersebut diragukan. Patokan pertama aktifitas rukyat secara astronomis adalah terjadinya ijtimak atau konjungsi, jika hal ini belum terjadi, dipastikan bahwa klaim terlihatnya hilal adalah keliru (dalam hal ini secara astronomis).

Berdasarkan penelitian intensif yang dilakukan oleh para pakar hisab (astronomi) terdapat beberapa kelemahan rukyat:

1. Jauhnya jarak hilal (bulan) dari permukaan bumi (mencapai sekitar $40.000 \quad$ kilometer), sementara bulan hanya mengisi sudut sekitar $2 \frac{1}{2}$ derajat yang berarti hanya mengisi 1/80 sudut pandang mata manusia tanpa menggunakan alat. Ini berarti hilal hanya mengisi sekitar 1,25 $\%$ dari pandangan, oleh sebab itu pengaruh benda sekitar yang mengisi $\quad 98,75 \%$ sangatlah besar.

2. Hilal hadir hanya sebentar saja (sekitar 15 menit s.d. 1 jam), padahal pandangan mata sering terhalang oleh awan yang banyak terdapat di negara tropis dan basah karena banyaknya lautan seperti Indonesia. Karena lembabnya permukaan lautan maupun daratan didekatnya maka hasil penguapannya membentuk awan yang mengumpul di dekat permukaan di sekitar ufuk. Justru pada ketinggian yang rendah disekitar ufuk inilah hilal diharapkan hadir dan dapat dilihat. 
3. Keadaan lain yang menyulitkan pelaksanaan rukyah hilal adalah kondisi sore hari, terutama yang menyangkut pencahayaan, karena kemuncuan hilal sangat singkat maka rukyah harus dilaksanakan secepat mungkin setelah matahari terbenam. Pada saat itu meskipun matahari sudah di bawah ufuk, cahayanya masih terlihat benderang, selanjutnya akan muncul cahaya kuning keemasan (cerlang petang). Cahaya ini sangat kuat dan nyaris menenggelamkan cahaya hilal yang sangat redup.

4. Banyaknya penghalang di udara berupa awan, asap kenderaan, asap pabrik, dan lain-lain.

5. Kesulitan lainnya, hilal pada umumnya terletak tidak jauh dari arah matahari, yaitu hanya beberapa derajat ke sebelah utara atau selatan tempat terbenamnya matahari.

6. Adanya faktor psikis (kejiwaan/mental), sebab melihat adalah gabungan antara proses jasmani dan proses rohani (psikis), yang dominan adalah proses psikis. Sekalipun ada benda, citra benda di selaput jala dan isyarat listrik yang menyusuri urat saraf menuju otak, seseorang tidak akan melihat apapun jika otaknya tidak siap, misalnya karena melamun, maka dalam hal ini proses psikis tidak terjadi, sehingga proses melihat tidak terjadi pula. Sebaliknya, meskipun proses psikis tidak ada-misalnya bendanya tidak ada sehingga tidak ada citra benda, tidak ada isyarat optik maupun listrik-namun jika proses mentalnya hadir, maka ia 'merasa' dan kemudian 'mengaku' melihat. Dalam ilmu psikologi, proses ini dikenal dengan istilah halusinasi, yaitu berupa perasaan ingin sekali berjumpa atau sangat rindu pada benda yang akan dilihat, atau merasa yakin bahwa bendanya pasti ada. Jika terhadap benda yang besar seperti manusia, gunung, gedung, dan lain-lain bisa salah lihat, apalagi terhadap 
hilal yang jauh lebih kecil

bahkan redup. ${ }^{5}$

Dengan alasan-alasan di atas manusia mulai berpikir untuk mencari solusi dari kenyataan ini, hisab-falak agaknya menjadi pilihan. Namun lagilagi hal ini tidaklah mudah, sebab hal ini terkait juga dengan aspek syariat (fikih). Karena itu perbincangan seputar ini semakin hangat dan menarik untuk diteliti dan di diskusikan.

\section{Hisab}

1. Hisab Imkanur Rukyat yaitu awal bulan dinyatakan telah terjadi bila setelah terbenam matahari (setelah terjadi ijtimak), dan pada saat itu hilal dimungkinkan untuk dapat dilihat (rukyat). Dalam hal ini yang menjadi acuan adalah penentuan kriteria visibilitas hilal untuk dapat teramati. Dalam prakteknya, para ahli hisab berbeda pendapat dalam menetapkan kriteria visibilitas hilal untuk dapat teramati, disamping ahli hisab juga masih berbeda dalam menetapkan apakah ketinggian hilal saja yang menjadi pedoman atau juga memperhatikan jarak busur (angular

\footnotetext{
${ }^{5}$ Farid Ruskanda, 100 Masalah Hisab \& Rukyat, Telaah Syari'ah, Sains dan Teknologi, h. 41-46.
}

distance) bulan-matahari serta faktorfaktor lainnya seperti umur hilal sejak ijtimak, besar cahaya matahari yang diterima bulan (franction illumination), dan lain-lain. ${ }^{6}$

Di indonesia konsep ini digunakan oleh Kementrian Agama dalam menetapkan awal Ramadhan, Syawal, dan Dzulhijah. Sejauh ini, kriteria visibilitas hilal (standar kemungkinan hilal dapat dilihat) yang berkembang sangat beragam sekali, bergantung situasi dan kondisi masingmasing, antara lain:

- Imkanur Rukyat Kementrian Agama RI dan Forum MABIMS

Kriteria ini mensyaratkan, jika setelah terbenam matahari (pada hari terjadinya ijtimak) hilal sudah berada di atas ufuk minimal 2 derajat dengan jarak busur bulan-matahari minimal 3 derajat, ditambah umur bulan 8 jam setelah terjadi ijtimak, maka ini menandakan telah masuknya bulan baru. Jika salah satu kriteria in tidak terpenuhi maka ketika itu belum dinyatakan sebagai bulan baru, namun

\footnotetext{
6 Arwin Juli Rakhmadi Butar-Butar, Telaah Singkat Berbagai Konsep dan Metodologi Hisab, (Kairo, ICMI ORSAT 2007), h. 3 .
} 
masih terhitung sebagai hari terakhir dari bulan yang sedang berjalan (istikmal). Ringkasnya: (1) hilal minimal 2 derajat di atas ufuk, (2) Jarak lengkung bulan-matahari (jarak busur) minimal 3 derajat, (3) Umur bulan minimal 8 jam setelah ijtimak, (4) Prinsip wilayatul hukmi.

Model ini digunakan oleh pemerintah Republik Indonesia yang diambil melalui laporan hasil hisab dan kesaksian hilal di seluruh Indonesia. Keputusan diambil melalui sidang itsbat yang ditangani oleh Badan Hisab \& Rukyat Kementrian Agama yang melibatkan berbagai unsur, antara lain MUI, ormas-ormas (NU, Muhammadiyah, PERSIS, dan lainlain), unsur perguruan tinggi, pakar dan praktisi tenaga ahli, staf planetarium dan observatorium, staf Badan Meteorologi dan Geofisika, serta pejabat Kementrian Agama RI yang hanya berfungsi sebagai fasilitator. Setelah mencapai kata sepakat meski tidak utuh, pemerintah (dalam hal ini menteri agama) mengukuhkan melalui surat keputusan serta mengumumkan secara langsung kepada masyarakat melalui televisi dan media lainnya. Kriteria ini juga diadopsi oleh beberapa negara Asia Tenggara yang tergabung dalam Forum MABIMS (MenteriMenteri Agama Brunai Darussalam, Indonesia, Malaysia, dan Singapura). ${ }^{7}$

Sejauh ini,banyak kalangan menilai bahwa kriteria ini sebagai penengah antara hisab dan rukyat atau tepatnya antara NU dan Muhammadiyah. Namun tidak dipungkiri bahwa teori ini (khususnya dikalangan ahli astronomi) masih di perdebatkan keakuratan kriteria visibilitasnya, artinya ambang batas yang ditetapkan 2 derajat, jarak bujur 3 derajat, dan umur bulan 8 jam dipandang sangat mustahil untuk dapat teramati dengan mata terutama dalam konteks dan lokasi Indonesia, sehingga terkesan mengabaikan ilmu pengetahuan. Sehingga dalam hal ini diperlukan tinjauan lebih lanjut tentang kriteria visibilitas hilal untuk dapat teramati, dan sejauh ini usaha-usaha tindak lanjut tersebut terus berjalan meski belum mendapatkan jawaban yang menenteramkan.

\section{- Limit Danjon}

Andrea Danjon (pakar astronomi dari Prancis) memberi batas/limit hilal

${ }^{7}$ Ibid, h. 231 
AL-MARSHAD: JURNAL ASTRONOMI ISLAM DAN ILMU-ILMU BERKAITAN

ISSN 2442-5729 (print) || ISSN 2598-2559 (online), http://jurnal.umsu.ac.id/index.php/almarshad

DOI: https://doi.org/10.30596/jam.v4i2.2441

Published December 2018

dapat teramati jika; tinggi hilal minimal

2 derajat dan jarak lengkung bulanmatahari (jarak busur) minimal 7 derajat. Limit (kriteria) ini banyak diadopsi oleh berbagai kalangan hingga dikenal-lah limit ini dengan limit Danjon.

- Kesepakatan Istanbul (Konferensi Almanak Islam tahun 1978 M)

Dalam muktamar internasional yang diadakan di Istanbul Turki pada tanggal 26-29 Dzulhijah1398 H/ 27-30 November 1978 M dimana Indonesia sebagai salah satu peserta muktamar, menetapkan keputusan sebagai berikut:

- asal penetapan hilal adalah dengan rukyat (baik dengan mata atau dengan observasi ilmiah)

- masuknya awal bulan secara syar'i ditandai dengan hilal sudah wujud di atas ufuk setelah terbenam matahari (setelah terjadi ijtimak)

- jarak sudut bulan-matahari minimal 8 derajat

- $\quad$ tinggi hilal minimal 5 derajat

- Kriteria Ilyas
Mohammad Ilyas ${ }^{8}$ (seorang ahli astronomi dari Malaysia) mengungkapkan bahwa visibilitas hilal dapat teramati jika: (1) jarak busur bulan-matahari minimal 10,5 derajat, (2) tinggi hilal minimal 5 derajat.

\section{- Kriteria LAPAN}

Kriteria ini dikemukakan oleh LAPAN (Lembaga Antariksa dan Penerbangan Nasional) sebagai tindak lanjut fatwa MUI tahun $2004 \mathrm{M}$ untuk mengusahakan adanya kriteria penetapan awal bulan kamariah untuk dijadikan pedoman bersama. Kriteria ini didasarkan kajian astronomis yang dilakukan terhadap data rukyatul hilal di Indonesia (sejak tahun 1962 M - 1997 M). Kriteria ini menetapkan awal bulan ditandai dengan adanya kesesuaian antara beda azimut dan tinggi hilal, bila salah satu tidak terpenuhi maka dianggap belum masuk bulan baru. Kriteria-kriteria ini adalah: (1). Umur hilal minimal 8 jam. (2). Tinggi bulan

\footnotetext{
${ }^{8}$ Mohammad Ilyas adalah orang yang pertama kali mencetuskan adanya garis tanggal kamariah (Khath at-târîkh al-qamarî) yaitu garis yang memisahkan dua belahan bumi dimana satu diantaranya hilal lebih dahulu terlihat (wujud) sementara belahan bumi lain belum terlihat (belum wujud).
} 
minimal tergantung beda azimut bulanmatahari, yaitu sebagai berikut:

$\begin{array}{cc}\text { Beda Azimut } & \text { Tinggi Minimum }\left(^{\circ}\right) \\ 0,0 & 8,3 \\ 0,5 & 7,4 \\ 1,0 & 6,6 \\ 1,5 & 5,8 \\ 2,0 & 5,2 \\ 2,5 & 4,6 \\ 2,0 & 4,0\end{array}$

Kriteria ini dalam kenyataannya belum teraplikasikan dan belum pula terpublikasikan, karena seperti lazimnya sebuah temuan baru, diperlukan uji kelayakan dan kepantasan baik secara syariat maupun sains, sekaligus juga diperlukan sosialisasi menyeluruh di tengah masyarakat terutama ormasormas.

- kriteria Ibn Yunus

Ibn Yunus (Ali bin Abdurrahman bin Ahmad bin Yunus alMishry) (w. 399 H), seorang ahli falak mesir yang banyak memiliki akses dalm ilmu falak, seperti dikutip Ibn al-Majdi (w. $850 \mathrm{H}$ ), ia memberi batasan hilal dapat teramati jika:

- Jarak busur (Ibn Yunus sebagaimana dikutip Ibn al-
Majdi menyebutnya dengan had an-nûr) minimal 10 derajat.

- $\quad$ Tinggi hilal minimal 6 atau 6,5 derajat.

- Busur edar bulan (mukts) minimal 8 derajat.

Masih banyak lagi kriteriakriteria yang ada dalam sistem imkanur rukyat ini yang terus berkembang sesuai dengan hasil pengkajian dan observasi di masing-masing lokasi.

\section{E. Matlak Global}

Istilah matlak dalam studi kalender hijriah adalah batas geografis keberlakuan rukyat. ${ }^{9}$ Dalam pengertian ini, kemudian muncul terminologi Ikhtilâf al-mathla'. Menurut aliran ini penampakan hilal Ramadhan atau hilal Syawal di suatu wilayah harus diikuti pula oleh wilayah lain yang belum melihat hilal. Dengan kata lain, bahwa hasil rukyat bersifat global, artinya perbedaan tempat penampakan hilal tidak berpengaruh pada perbedaan memulai puasa atau hari raya (Idul Fitri) untuk seluruh wilayah di bumi ini, sehingga apabila suatu wilayah telah

9 Susiknan Azhari, Ilmu Falak Perjumpaan Khazanah Islam dan Sains Modern, (Yogyakarta, Suara Muhammadiyah, 2007), h. 121. 
AL-MARSHAD: JURNAL ASTRONOMI ISLAM DAN ILMU-ILMU BERKAITAN

ISSN 2442-5729 (print) || ISSN 2598-2559 (online), http://jurnal.umsu.ac.id/index.php/almarshad

DOI: $\underline{\text { https://doi.org/10.30596/jam.v4i2.2441 }}$

Published December 2018

melihat hilal, maka wilayah lain berpedoman pada hasil rukyat wilayah tersebut, tanpa membedakan jauh dekatnya antar wilayah, persoalan geografis dan astronomis lainnya. ${ }^{10} \mathrm{Di}$ Indonesia pendapat ini dikembangkan oleh Hasbi ash-Shiddieqy, Hizbut Tahrir, dan lain-lain. ${ }^{11}$

\section{F. Hisab Wujudul Hilal}

Metode ini adalah yang dipakai oleh Muhammadiyah dan PERSIS (pasca 2002 M). Aliran ini berpendapat bahwa awal bulan kamariah dimulai sejak terbenam matahari setelah terjadi ijtimak dan pada saat itu hilal sudah berada di atas ufuk dan telah wujud. Yang dimaksud hilal telah wujud adalah bila matahari terbenam lebih dahulu dari terbenamnya bulan atau bulan terbenam setelah matahari terbenam(moon set after sunset) dengan tiada batasan tertentu, patokannya hilal sudah wujud (di atas ufuk) walaupun hanya $1^{\circ}$ tingginya dan beberapa menit saja kemunculannya. ${ }^{12}$ Secara umum

${ }^{10}$ Ibid, h. 122.

${ }^{11}$ Ibid, h. 134

12 Abdur Rachim, Penetapan Awal Bulan Qamariyah Perspektif Muhammadiyah, 2002, (Yogyakarta: Majelis Tarjih Dan Pengembangan Pemikiran Islam Pimpinan Pusat Muhammadiyah, 2007), h. 2. kriteria yang dijadikan dasar untuk menetapkan awal bulan kamariah oleh metode ini adalah:

- Ijtimak terjadi sebelum terbenam matahari (ijtimâ ${ }^{\text {' }}$ qablal ghurûb).

- Awal bulan kamariah dimulai sejak saat terbenam matahari setelah terjadi ijtimak.

- Hilal sudah berada di atas ufuk pada saat matahari terbenam.

Apabila pada saat terbenam matahari setelah terjadi ijtimak(akhir bulan kamariah) hilal sudah berada (wujud) di atas ufuk ${ }^{13}$, maka sejak saat itu mulai masuk (tanggal 1) bulan baru kamariah. Sebaliknya, jika pada saat itu hilal masih berada di bawah ufuk ${ }^{14}$, maka saat itu masih dianggap sebagai hari terakhir dari bulan kamariah yang sedang berlangsung.

Di Indonesia konsep ini digunakan oleh Muhammadiyah dan Persis (pasca 2002 M) dalam menetapkan awal Ramadhan, Syawal, dan Dzulhijah serta bulan-bulan lainnya dengan kriteria: setelah matahari

13 Dalam praktik perhitungan, posisi hilal sudah berada di atas ufuk jika hasil perhitungan menunjukkan positif $(+)$.

14 Dalam praktik perhitungan, posisi hilal masih berada di bawah ufuk jika hasil perhitungan menunjukkan negativ $(+)$. 
terbenam (setelah terjadi ijtimak), hilal sudah berada di atas ufuk (hilal sudah positif) ditambah prinsip wilayatul hukmi (khusus Muhammadiyah) atau hilal sudah wujud di seluruh Indonesia (khusus Persis). Prinsip wilayatul hukmi adalah jika hilal membelah wilayah kesatuan (indonesia), di sebagian wilayah hilal sudah wujud dan di wilayah lain belum, maka wilayah yang belum wujud (timur) mengikut wilayah yang sudah wujud (barat).

\section{G. Penutup}

Penetapan awal Ramadhan, Syawal dan Dzulhijah adalah persoalan ijtihad, sehingga sangat memungkinkan terjadinya perbedaan pandangan dan pendapat. Pernyataan Nabi Saw "faqdurû lahu" dan "fa in ghumma “alaikum fa akmilû al- 'iddah tsalâtsîn”, hadis pertama tertuju pada orang-orang yang mengerti ilmu hisab-falak, hadis kedua tertuju pada orang awam (sesuai dengan pernyataan Ahmad Muhammad Syakir yang mengutip pendapat Ibn Suraij) ditambah argumen-argumen lainnya.

Berdasarkan beberapa penelitian menunjukkan bahwa dalam rukyat terdapat banyak kelemahan dipandang dari sudut IPTEK, sehingga metode ini perlu dielaborasi dengan fasilitas teknologi modern (dalam hal ini hisabfalak). Penelitian dan perhitungan yang dilakukan para pakar hisab-falak menunjukkan bahwa data yang dihasilkan sudah selalu memberikan hasil yang sangat akurat tanpa menyisakan perbedaan yang berarti. Sehingga tak berlebihan banyak ulama kontemporer mendukung bahkan mewajibkan penggunaan data hisabfalak dalam menentukan awal bulan kamariah terkhusus Ramadhan, Syawal dan Dzulhijah.

Hisab pada dasarnya adalah bangunan keilmuan, maka sangat dipengaruhi oleh wacana epistema masing-masing. Maka wujudul hilal yang diusung Muhammadiyah dan imkanur rukyat oleh Pemerintah memiliki ciri sendiri-sendiri. Maka, batas equilibrium (baca: keseimbangan) hisab dan imkanur rukyat terletak pada sampai mana keduanya saling berkomunikasi, bukan malah mengambil jarak. Dengan demikian masing-masing tidak terjebak pada intellectual arrogance. Untuk itu sangat perlu dikembangkan hubungan asosiatif literal-inderawi dengan nalar rasional- 
AL-MARSHAD: JURNAL ASTRONOMI ISLAM DAN ILMU-ILMU BERKAITAN

ISSN 2442-5729 (print) || ISSN 2598-2559 (online), http://jurnal.umsu.ac.id/index.php/almarshad

DOI: https://doi.org/10.30596/jam.v4i2.2441

Published December 2018 ilmiah untuk membangun kalender

Hijriah ke depan.

\section{Daftar Pustaka}

Al-Jaziri, Abdurrahman. (2001). Kitâb al-Fiqh 'alâ al-Madzâhib alArba'ah. Kairo: Mu'assasah alMukhtar.

Al-Qaradhawi, Yusuf. (2003). Fiqh alShiyâm. Kairo: Maktabah Wahbah.

Azhari, Susiknan. (2007). Ilmu Falak; Perjumpaan Khazanah Islam dan Sains Modern. Yogyakarta: Suara Muhammadiyah.

Butar - Butar, Arwin Juli Rakhmadi. (2007). Ilmu Falak dan Peranannya dalam Islam (Teori dan Praktek Beberapa Perhitungan). Kairo: Departemen Intelektual dan Kerohanian Himpunan Mahasiswa Medan (HMM).

Butar - Butar, Arwin Juli Rakhmadi. (2007). Aspek Astronomis Penentuan Awal Bulan Qamariyah; Karakteristik Hilal dan Plus-Minus Hisab Astronomis. Kairo: ICMI ORSAT.
Butar - Butar, Arwin Juli Rakhmadi. (2007). Pengantar Ilmu Falak, Kairo: Gema Insani.

Pimpinan Pusat Muhammadiyah. (t.t) Himpunan Putusan Majelis Tarjih Muhammadiyah, Pikiran Pembaca Muhammadiyah, Yogyakarta.

Ruskanda, Farid. (1996). 100 Masalah Hisab \& Rukyat; Telaah Syari'ah, Sains dan Teknologi, Gema Insani Press.

Syakir, Ahmad Muhammad. (1407) Awâ'il al-Syuhûr al-'Arabiyah, Hal Yajûzu Syar'an Itsbâtuhâ bi’l Hisâbât al-Falakiyyah. Kairo: Maktabah Ibn Taimiyah. 